\title{
Identifikasi Atribut Sepeda Motor Listrik terhadap Niat Membeli: Kasus di Indonesia
}

\author{
Ade Ana Pratiwi, Berto Mulia Wibawa, dan Imam Baihaqi \\ Departemen Manajemen Bisnis, Institut Teknologi Sepuluh Nopember (ITS) \\ e-mail: ibaihaqi@mb.its.ac.id
}

\begin{abstract}
Abstrak-Sepeda motor menjadi alat transportasi yang banyak digunakan di Asia Tenggara. Salah satunya di negara Indonesia. Penggunaan sepeda motor merupakan salah satu penyumbang gas emisi buang yang dapat mencemari lingkungan. Munculnya sepeda motor listrik sebagai produk inovasi menjadi salah satu cara dalam menyelesaikan permasalahan tersebut. Pada penelitian bertujuan untuk mengidentifikasi karakteristik calon pelanggan, menganalisis atribut sepeda motor listrik yang menjadi preferensi atau kecenderungangan konsumen dalam memiliki niat membeli sepeda motor listrik. Selain itu juga untuk mengetahui atribut yang mempengaruhi calon konsumen dalam mengadopsi sepeda motor listrik. Untuk mencapai tujuan penelitian, maka teknik pengolahan dan analisis data yang digunakan adalah analisis deskriptif dan Multriatribut. Pengumpulan data dilakukan menggunakan kuesioner online yang disebarkan kepada 300 sampel yang tersebar di 34 provinsi yang ada di Indonesia. terdapat temuan yang menunjukkan bahwa atribut yang memiliki kepentingan paling tinggi adalah keamanan dan waktu pengisian baterai. Terdapat implikasi manajerial yang dapat diaplikasikan oleh pemasar produk sepeda motor listrik dengan memperhatikan karakteristik konsumen, diantaranya adalah menyelenggarakan acara yang bertujuan untuk memberikan informasi pengetahuan produk kepada para calon konsumen.
\end{abstract}

Kata Kunci-Atribut Produk, Multiatribut Fishbein, Sikap Konsumen, Sepeda Motor Lsitrik

\section{PENDAHULUAN}

$\mathrm{P}$ ENDUDUK pada sejumlah kota di Asia Tenggara menggunakan kendaraan sepeda motor sebagai alat transportasi utama dalam perkotaan. Salah satunya di kota-kota di Indonesia yang sebagian besar populasi penduduknya menggunakan motor sebagai alat transportasinya. Mahalnya harga kendaraan mobil menjadi salah satu alasan masyarakat Indonesia lebih memilih menggunakan sepeda motor. Selain itu, sepeda motor dirasa penggunaanya lebih praktis dari pada transportasi umum. Kendaraan sepeda motor di Indonesia tidak hanya sebagai moda transportasi dalam kegiatan sehari-hari, akan tetapi juga salah satu alat atau sumber penghasilan untuk masyarakat. Ketua Asosiasi Industri Sepeda Motor Indonesia (AISI) menjelaskan bahwa peta industri kendaraan roda dua khususnya sepeda motor memberikan kontribusi hampir 30\% ke dalam Anggaran Pendapatan dan Belanja Negara (APBN) melalui pajak yang dihasilkan [1]. Hal ini menyebabkan penjualan motor di Indonesia meningkat setiap tahunnya.

Jumlah penggunanan sepeda motor yang meningkat setiap tahunnya, menyebabkan peningkatan polusi udara yang disebabkan gas emisi yang dihasilkan oleh sepeda motor. Indonesia mencatat peningkatan emisi $\mathrm{CO}_{2}$ sebesar $18 \%$ sepanjang 2012 hingga 2017 yang disebabkan karena meningkatnya emisi dari pembangkitan listrik, sektor industri, dan sektor transportasi [2]. Emisi sendiri adalah salah satu penyumbang perubahan iklim dan pemanasan global. Emisi $\mathrm{CO}_{2}$ menjadi salah satu pemicu terjadinya efek rumah kaca, dimana hal ini akan mempengaruhi perubahan iklim. Perubahan iklim ini akan berdampak pada produksi pangan, limpasan air tahunan, kasus kekurangan gizi dan penyakit diare, bioma ekosistem, hingga perubahan suhu [2]. Berbagai upaya dilakukan untuk mengurangi penggunaan bahan bakar fosil pada sektor transportasi darat. Salah satu hal yang dilakukan adalah dengan penggunaan sepeda motor listrik.

Sepeda motor listrik merupakan sebuah kendaraan yang inovatif dan dianggap berdampak pada lingkungan [3]. Sepeda motor listrik diharapkan menjadi solusi yang berkelanjutan untuk menjawab tantangan global sebagai akibat dari kelangkaan energi dan pencemaran lingkungan. Sepeda motor listrik memiliki kelebihan dari pada kendaraan berbahan bakar mesin biasa, yaitu tidak dihasilkannya emisi gas buang. Perbandingan utama antara kendaraan listrik dengan kendaraan konvensional yang ditenagai oleh Internal Combustion Engine (ICE) adalah pada rantai penggerak kendaraan, dimana penyimpanan energi yang disimpan serta perilaku yang diperlukan untuk mentransmisikan daya ke kendaraan dapat lebih mudah dibandingkan dengan kendaraan konvensional [3]. Selain itu juga sepeda motor listrik mendukung tren perkembangan masa depan untuk keunggulan energi yang rendah emisi.

Presiden Indonesia Joko Widodo menerbitkan Peraturan Presiden nomor 55 tahun 2019 mengenai kendaraan listrik. Peraturan presiden ini akan menetapkan kebijakan untuk mempercepat program pengembangan kendaraan bermotor listrik di Indonesia. Peraturan ini mengatur tentang pengaturan tahapan perisapan dalam mendukung keberadaan kendaraan listrik seperti persiapan infrastruktur pengisian bahan bakar serta pengaturan tarif tenaga listrik. Selain itu juga peraturan ini mengatur tentang percepatan perkembangan kendaraan listrik dengan membuat kebijakan mengenai penelitian, pengembangan, dan inovasi industri kendaraan bermotor yang berbasis baterai. Dimana pemerintah bekerjasama dengan perusahaan industri, perguruan tinggi serta lembaga penelitian dan pengembangan untuk melakukan riset teknologi industri kendaraan bermotor listrik berbasis baterai. Selanjutnya 
pengaturan mengenai teknis kendaraan bermotor listrik seperti, pendaftaran tipe dan nomor identifikasi, dan upaya pemberian insentif pada industri. Hal ini merupakan upaya pemerintah untuk percepatan pengembangan industri kendaraan bermotor listrik berbasis baterai dalam negeri. Menurut hasil wawancara yang dilakukan dengan salah satu pegawai GESITS [4] bahwa saat ini kendala yang berasal dari pemerintah yaitu tentang pajak kendaraan listrik yang belum diatur, serta dukungan yang diberikan hanya dalam bentuk kerjasama dengan BUMN sebagai bentuk business to business saja. Secara teknis kendala utama ada pada baterai, dikarenakan 65 persen performa kendaraan listrik dipengaruhi baterai, sedangkan di Indonesia belum bisa memproduksi baterai dan sudah ada penelitian akan tetapi belum mencapai tahap tingkat kesiapan teknologi secara mass production.

Terdapat sekitar tiga perusahaan di Indonesia yang sudah mengembangkan dan memproduksi kendaraan sepeda motor listrik di Indonesia diantaranya yaitu PT Triangle Motorindo yang produk sekuter listriknya diberi nama Viar Q1, PT Gesits Technologies Indo dengan produk yang dinamakan Gesits, dan PT Juara Bike yang produk skuternya diberi nama Selis (Sekuter Listrik [5]. Ketiga perusahaan yang memproduksi sepeda motor listrik ini memiliki kesamaaan yaitu dalam sumber tenaga menggunakan listrik dan sudah dilengkapi dengan surat tanda kepemilikan kendaraan (STNK), sehingga sudah legal untuk dibawa berkendaraan di jalan raya [5]. Akan tetapi dari segi desain dan harga ketiga produk dari perusahaan ini saling bersaing. Viar Q1 memiliki desain yang bergaya retro dengan lekuk bodi yang membulat. Sementara Gesits lebih sporty akibat bentuk garis tajam dan tegas pada lekuk bodi. Selis juga memiliki desain yang cenderung retro atau bentuk bodi cenderung kotak. Ketiga sekuter listrik ini sudah menggunakan digital speedometer [5] .Dilansir dari sebuah berita harian Kompas (2019), pertumbuhan industri sepeda motor listrik di Indonesia masih banyak rintangan yang harus dihadapi dari mulai regulasi pemerintah hingga infrastruktur pendukung operasi sepeda motor listrik. Infrastruktur yang belum tersedia seperti charging station dan jumlah baterai untuk pengganti. Selain itu, harga produk yang tinggi menjadi pertimbangan utama masyarakat dalam menggunakan sepeda motor listrik. Sepeda motor listrik bisa dijual dengan kisaran harga 15-26 juta per unit. Penelitian ini penting untuk dilakukan di Indonesia, dikarenakan Indonesia merupakan emerging market sehingga memiliki potensi pasar yang baik. Maka dari itu, penelitian ini dilakukan untuk mengidentifikasi atribut yang memengaruhi sikap konsumen pada produk sepeda motor listrik.

\section{LANDASAN TEORI}

\section{A. Perilaku Konsumen}

Perilaku konsumen merupakan tindakan yang dilakukan oleh individu, kelompok, atau organisasi dan sebuah proses untuk memilih, membeli, menggunakan, dan pembuanagn dari produk, jasa, pengalaman atau ide-ide untuk kepuasan kebutuhan yang berdampak pada proses yang ada pada konsumen dan masyarakat [6] . Dalam melakukan proses untuk
Tabel 1.

Definisi Operasional Variabel

\begin{tabular}{|c|c|c|}
\hline Kode & Atribut & Definisi \\
\hline B1 & Harga Pembelian & Harga beli kendaraan \\
\hline B2 & Kecepatan & $\begin{array}{l}\text { Kecepatan yang dapat ditempuh } \\
\text { sepeda motor listrik }\end{array}$ \\
\hline B3 & Level Emisi & Jumlah emisi yang dikeluarkan. \\
\hline B4 & Lama Pengisian & $\begin{array}{l}\text { Lama atau waktu yang dibutuhkan } \\
\text { dalam mengisi bahan bakar }\end{array}$ \\
\hline B5 & Reliability & $\begin{array}{l}\text { Seberapa baik mesin, peralatan, } \\
\text { atau sistem bekerja. }\end{array}$ \\
\hline B6 & Style & $\begin{array}{l}\text { Bentuk atau desain tertentu } \\
\text { (Cambridge Dictionary). Dalam } \\
\text { hal ini berupa desain dari sepeda } \\
\text { motor listrik. }\end{array}$ \\
\hline B7 & Safety & $\begin{array}{l}\text { Kondisi tidak berada dalam } \\
\text { bahaya atau tidak berbahaya. }\end{array}$ \\
\hline B8 & Agility & $\begin{array}{l}\text { Kemampuan untuk bergerak } \\
\text { dengan cepat dan mudah. }\end{array}$ \\
\hline B9 & Biaya operasional & $\begin{array}{l}\text { Biaya yang dikeluarkan ketika } \\
\text { melakukan suatu kegiatan. }\end{array}$ \\
\hline B10 & acceleration & $\begin{array}{l}\text { Tingkat perubahan kecepatan. } \\
\text { Percepatan laju pada sepeda motor } \\
\text { listrik. }\end{array}$ \\
\hline
\end{tabular}

memenuhi kebutuhannya sekarang konsumen juga mempertimbangkan dampak tingkah lakunya terhadap lingkungan sehingga dalam membuat keputusan tentang makanan, pakaian, bangunan tempat kerja, dan mobil yang dikendarai akan mempertimbangkan aspek lingkungan [7].

Perilaku konsumen dapat dipengaruhi oleh faktor internal maupun eksternal yang tidak dapat dipengaruhi oleh pemasar. Pengaruh faktor internal dapat meliputi persepsi, pembelajaran, memori, motif, kepribadian, emosi, dan sikap. Sedangkan pengaruh faktor eksternal meliputi budaya, sub-budaya, demografi, status sosial, kelompok referensi, dan keluarga[8]. Adanya pengaruh tersebut menyebabkan konsumen kemudian mengambil keputusan secara kognitif, habitual ataupun efektif [7]. Keputusan kognitif adalah keputusan yang disengaja dan rasional, keputusan habitual terjadi karena keterbiasaan, sedangkan keputusan efektif terjadi akibat emosi yang berasal dari konsumen. Proses pengambilan keputusan pembelian konsumen terdapat lima tahap yang terdiri dari pengenalan masalah, pencarian informasi, evaluasi alternatif, pembelian produk, dan evaluasi pasca pembelian [9].

\section{B. Niat Beli Konsumen Terhadap Kendaraan Listrik}

Pada penjelasan Engel, J.F., Et.al. (1973) tentang proses pengambilan keputusan dalam perilaku konsumen. Niat beli konsumen terjadi pada tahap evaluasi alternatif dengan penawaran yang diberikan beberapa merek berbeda. Niat beli sendiri dapat didefinisikan sebagai sebuah perilaku konsumen yang timbul berdasarkan pengalaman dalam melakukan tindakan memilih, menggunakan, dan mengonsumsi suatu produk tertentu [10]. Niat beli yang terdapat dalam diri dapat menimbulkan keputusan pembelian, namun pembelian tersebut tidak selalu berhasil karena terdapat faktor pengaruh sifat orang lain dan situasi yang tidak terduga. Selain itu, sikap niat beli konsumen berkaitan juga dengan kualitas yang dirasakan, terutama terhadap merek yang tidak dikenal [11]. Sedangkan menurut Chang \& Wildt (1994 niat beli konsumen juga 
Tabel 2.

Nilai Kekuatan Kepercayaan Atribut Sepeda Motor Listrik

\begin{tabular}{clcc}
\hline \hline & \multicolumn{1}{c}{ Atribut } & bi & Kategori \\
\hline H7 & Keamanan & 4,37 & $\begin{array}{c}\text { Sangat } \\
\text { penting } \\
\text { Sangat }\end{array}$ \\
& Lama Pengisian Baterai & 4,21 & $\begin{array}{c}\text { Penting } \\
\text { H4 }\end{array}$ \\
H9 & Biaya Pengisian Baterai & 4,14 & Penting \\
H5 & Keandalan & 4,08 & Penting \\
& Agility (Kemampuan bergerak & & Penting \\
H8 & dengan cepat) & 4,01 & \\
H3 & Level Emisi & 4,00 & Penting \\
H1 & Harga & 3,99 & Penting \\
H10 & Percepatan & 3,96 & Penting \\
H2 & Kecepatan & 3,79 & Penting \\
H6 & Style (Desain) & 3,65 & Penting \\
\hline \hline
\end{tabular}

dipengaruhi oleh nilai yang dirasakan konsumen serta harga yang ditawarkan oleh perusahaan.

Niat beli terhadap kendaraan listrik dapat diartikan sebagai keputusan untuk menggunakan teknologi yang tergolong baru atau bisa disebut early adopter. Penelitian terdahulu menyebutkan bahwa niat beli konsumen pada kendaraan listrik timbul akibat keinginan untuk melindungi lingkungan dari kerusakan, salah satunya dengan pengurangan emisi karbon [12]. Keinginan tersebut didampingi dengan kelengkapan atribut yang yang diberikan oleh kendaraan listrik sehingga menimbulkan kenyamanan dalam menggunakan [13]. Nilai kekuatan kepercayaan atribut sepeda motor listrik dapat dilihat pada Tabel 2 .

\section{Theory of Reasoned Action}

Theory of Reasoned Action (TRA) adalah teori yang dibuat oleh Fishbein dan Ajzen yang membahas tentang niat perilaku pelanggan tersebut. Pada teori ini menjelaskan niat perilaku menjadi suatu fungsi dan sikap seseorang dalam melakukan tindakan tertentu pada norma subyektif yang dimiliki [14]. Maka dari itu, suatu tindakan yang dilakukan konsumen dapat diprediksi yang berawal dari sikap menjadi tindakan jika ada korelasi antara niat dan perilaku. Menurut Ajzen \& Fishbein (1997). Sikap konsumen tersebut menggambarkan evaluasi konsumen terhadap suatu hal dan perilaku yang menjadi satu atau rangkaian kegiatan yang dilakukan individu dan dapat ditulis.

Menurut Yu \& Wu (2007) perilaku konsumen TRA adalah dasar untuk memahami dan memprediksi perilaku pembelian. Dalam penggunaan TRA ditujukan untuk menganalisis keputusan berpikir non rutin sebagai pertimbangan sebelum melakukan pembelian [15]. Selain itu, hasil keputusan pemikiran konsumen yang rasional dan beralasan dari timbulnya banyak alternatif penawaran juga dianalisis [16]. Hal ini dapat diartikan bahwa kesiapan konsumen untuk melakukan suatu tindakan dapat berawal dari keinginan dan kesiapan konsumen untuk bertindak sesuai dengan yang dipikirkan.

\section{Model Sikap Multiatribut Fishbein}

Sikap Multiatribut dapat dilihat melalui tingkat kepercayaan dan tingkat evaluasi pada produk. Analisis multiatribut digunakan untuk mengetahui pembentukan dan perubahan sikap seseorang [17].

\section{METODE PENELITIAN}

\section{A. Desain Penelitian}

Penelitian ini merupakan penelitian deskriptif sesuai dengan tujuan penelitian untuk mengidentifikasi sikap konsumen terhadap atribut sepeda motor listrik. Data yang dibutuhkan adalah data primer mengenai demografi responden dan penilaian responden mengenai atribut sepeda motor listrik yang digunakan responden.

\section{B. Sampel}

Data yang digunakan dalam penelitian ini merupakan data yang berasal dari kuesioner yang disebarkan melalui Google Formulir kepada penggendara sepeda motor yang tersebar di seluruh Indonesia pada bulan November hingga bulan Desember 2019. Sampel dipilih menggunakan metode kuota sampling dengan jumlah minimal sampel 300 responden yang dibagi ke dalam 34 provinsi dengan kuota yang berbeda-beda sesuai dengan presentase jumlah penduduk.

\section{Metode Analisis Data}

Analisis data dilakukan dengan menggunakan analisis multriatribut Fishbein. Penelitian menggunakan metode ini pernah dilakukan oleh Ramadhani (2019). Analisis data multiatribut Fishbein digunakan untuk mengukur sikap terhadap objek secara individu sehingga untuk menganalisis multiatribut secara keseluruhan sampel perlu dihitung kembali dengan menjumlah keseluruhan sikap responden dan membagi dengan jumlah responden. Berikut formulasi dari analisis multiatribut Fishbein:

$$
A_{\mathrm{o}} \sum_{i=1}^{n} b_{\mathrm{i}} e_{\mathrm{i}}
$$

Dimana,

$\mathrm{A}_{\mathrm{o}} \quad=$ Keseluruhan sikap seseorang terhadap suatu objek

$b_{i} \quad=$ Kepercayaan individu bahwa objek memiliki atribut $\mathrm{i}$

$\mathrm{e}_{\mathrm{i}} \quad=$ Aspek evaluasi individu terhadap atribut $\mathrm{i}$

$\Sigma \quad=$ Penjumlahan dari sejumlah atribut

$\mathrm{n} \quad=$ Jumlah atribut

Pada penelitian ini, sikap yang diteliti $\left(A_{o}\right)$ yaitu sikap konsumen pada produk sepeda motor listrik, $b i$ adalah seberapa kuat konsumen percaya pada atribut yang ada pada sepeda motor listrik dan ei adalah evaluasi terhadap atribut yang terdapat pada produk sepeda motor listrik. Analisis multiatribut dilakukan menggunakan skala Likert 5 poin. Tingkat kepercayaan individu memiliki kategori sangat tidak penting hingga sangat penting (1 sampai dengan 5) dan tingkat evaluasi kepercayaan memiliki kategori sangat buruk hingga sangat baik

(1 sampai dengan 5). Penentuan keseluruhan sikap seseorang terhadap suatu objek dilakukan dengan menggunakan skala interval. Skala dari kepercayaan, evaluasi, dan sikap dihitung dengan rumus sebagai berikut.

$$
\text { Skala } *=\frac{m-n}{b}
$$


Dimana,

$\mathrm{m}=$ Skor tertinggi yang mungkin terjadi

$\mathrm{n} \quad=$ Skor terendah yang mungkin terjadi

$\mathrm{b}=$ Jumlah skala penilaian yang terbentuk

*Skala sikap dihitung dengan $\mathrm{m}=\left(\mathrm{m}_{\mathrm{bi}} \mathrm{xm} \mathrm{m}_{\mathrm{ei}}\right)$ dan $\mathrm{n}=\left(\mathrm{n}_{\mathrm{bi}} \mathrm{Xn}_{\mathrm{ei}}\right)$

\section{Atribut Produk}

Variabel penelitian analisis multiatribut pada penelitian ini diambil dari penelitian Chiu \& Tzeng (1999) yang penelitiannya dilakukan China. Pada penelitian Chiu \& Tzeng (1999) terdapat 10 atribut yang dianalisis. Berikut daftar atribut yang digunakan (Tabel 1).

\section{ANALISIS DAN DISKUSI}

\section{A. Analisis Demografi}

Target responden yang telah ditetapkan adalah sejumlah 300 responden. Setelah dilakukan pengumpulan data, terdapat total 431 responden yang mengisi kuesioner. Namun, dari 431 responden yang lolos tahap screening dan memenuhi kuota sampling hanya 300 responden sehingga pencapaian target telah sesuai dengan yang ditetapkan.

Analisis demografi dilakukan untuk mengetahui profil dari responden yang terlibat dalam penelitian ini. Responden pada penelitian ini didominasi oleh laki-laki $(58,67 \%)$ dan berusia 18 hingga 27 tahun (69,33\%). Responden didominasi memiliki pekerjaan sebagai mahasiswa atau pelajar (73,33\%), jenjang pendidikan terakhir SMA atau sederajat $(63,67 \%)$, dengan ratarata pendapatan < Rp $1.500 .000(47 \%)$.

Analisis usage digunakan untuk mengetahui perilaku pembelian dan penggunaan sepeda motor dari responden penelitian. Intensitas penggunaan sepeda motor responden didominasi lebih dari 5 kali dalam seminggu $(85,67 \%)$, jenis sepeda motor yang menjadi prefernsi yaitu skuter matik $(69 \%)$ dan rata-rata pengeluaran bahan bakar dalam seminggu sebesar Rp 20.001 hingga Rp 30.000 (30,67\%).

\section{B. Analisis Multriatribut}

Pengolahan data dilakukan menggunakan analisis multiatribut Fishbein. Berdasarkan uji yang dilakukan menghasilkan kekuatan kepercayaan dari 10 atribut memiliki Cronbach's Alpha sebesar 0,926 dan evaluasi kepercayaan dari 10 atribut memiliki Cronbach's Alpha sebesar 0,910.

Setelah dilakukan uji reliabilitas, maka uji multiatribut Fishbein dilakukan untuk mengidentifikasi sikap responden terhadap atribut yang terkait dengan sepeda motor listrik dengan memperhatikan kekuatan kepercayaan dan evaluasi kepercayaan. Kekuatan kepercayaan terhadap atribut dalam sepeda motor listrik menggambarkan seberapa penting suatu atribut perlu dimiliki oleh sepeda motor listrik sehingga mendorong responden untuk membeli sepeda motor listrik. Evaluasi kepercayaan merupakan pendapat responden mengenai seberapa baik kondisi suatu atribut pada sepeda motor listrik yang digunakan. Kekuatan kepercayaan dari 10 atribut yang dianalisis menunjukkan bahwa terdapat 1 atribut yang sangat penting dan 9 atribut tergolong penting. Keamanan menjadi atribut yang paling penting dimiliki oleh sepeda motor
Tabel 3.

Nilai Evaluasi Kepercayaan Atribut Sepeda Motor Listrik

\begin{tabular}{clcc}
\hline \hline & \multicolumn{1}{c}{ Atribut } & ei & Kategori \\
\hline H3 & Level Emisi & 3,69 & Baik \\
H7 & Keamanan & 3,42 & Baik \\
H5 & Keandalan & 3,33 & Cukup Baik \\
H6 & Style (Desain) & 3,31 & Cukup Baik \\
H9 & Biaya Pengisian Baterai & 3,26 & Cukup Baik \\
H8 & Percepatan & 3,25 & Cukup Baik \\
& Agility (Kemampuan bergerak & & Cukup Baik \\
H10 & dengan cepat) & 3,23 & \\
H4 & Kecepatan & 3,19 & Cukup Baik \\
H1 & Lama Pengisian & 3,17 & Cukup Baik \\
H2 & Harga & 3,15 & Cukup Baik \\
\hline \hline
\end{tabular}

listrik. Pemerintah saat ini masih mengkaji akan standar atau regulasi yang akan diberlakukan terhadap sepeda motor listrik. Beberapa sepeda motor listrik saat ini sudah dilengkapi dengan fitur double disk brake, transmisi pulley, suspensi mono shock, LED daytime running light, dan HID projector head lamp. Pemerintah diwacanakan akan menggunakan spesifikasi standar UNR 136 yang secara teknis sudah ada pada sepeda motor listrik. Selain keamanan, lama pengisian baterai juga menjadi atribut sepeda motor listrik yang sangat penting. Lama pengisian baterai adalah bentuk dalam mengisi bahan bakar, berbeda dengan sepeda motor konvensional yang tidak memerlukan waktu lama dalam pengisian bakan bakarnya. Sepeda motor listrik memerlukan 2-3 jam dalam melakukan pengisian satu baterai dengan kapasitas tertentu.

Sedangkan biaya pengisian baterai, keandalan, agility dan level emisi memiliki rentang nilai yang berkisaran 4 dan tergolong penting. Atribut harga pada penelitian sebelumnya yang dilakukam oleh Chiu \& Tzeng (1999) menjadi perhatian yang pertama atau mendapatkan peringkat, hal ini berbeda pada penelitian ini. Adapun faktor yang dapat mempengaruhi perbedaan ini adalah kondisi demografi tempat dilakukannya penelitian, perbedaan karakteristik responden menjadi salah satu pengaruh.

Evaluasi kepercayaan dari 10 atribut yang dianalisis menunjukkan bahwa terdapat 2 atribut dalam sepeda motor listrik memiliki kondisi baik dan 8 atribut yang lain memiliki kondisi cukup baik (Tabel 3). Level emisi merupakan atribut yang memiliki nilai evaluasi paling baik diantara 9 atribut yang lain. Hal tersebut dikarenakan faktor bahan bakar yang digunakan tidak menghasilkan emisi gas buang, ini berkaitan pula dengan munculnya inovasi produk yaitu untuk membantu mengurangi emisi gas di Indonesia. Selanjutnya keamanan juga menjadi atribut dengan nilai evaluasi paling baik setelah atribut level emisi. Responden akan menggunakan produk yang telah teruji keamanannya sehingga dapat menimbulkan kepuasan dalam penggunaan produk. Saat ini setiap perusahaan penyedia sepeda motor listrik selalu meningkatkan kualitas produknya, dimana dari beberapa pameran dan review test drive didapatkan hasil yang dapat menjadi bahan pengembangan untuk produk sepeda motor listrik. Sehingga diharapkan produk sepeda motor listrik dapat sesuai dengan pasar atau target konsumen. Data yang telah diolah menghasilkan tingkat kepentingan dan evaluasi konsumen terhadap 10 atribut yang ada. Dari nilai kepentingan dan evaluasi yang didapatkan, dapat diketahui 
sikap keseluruhan konsumen pada suatu atribut dalam produk sepeda motor listrik dengan menggunakan perhitungan Fishbein (Tabel 4).

Dari perhitungan yang dilakukan menunjukkan bahwa dari 10 atribut mendapatkan tanggapan netral dari responden. Hal ini dikarenakan masih adanya pengembangan sepeda motor listrik dan sepeda motor listrik belum dikomersialisasikan karena masih terkendala akan regulasi pemerintah. Meskipun sepeda motor listrik sudah dapat dipesan secara online maupun offline dan sudah terdapat STNK. Regulasi pemerintah ini mengatur akan tingkat penggunaan sepeda motor listrik di Indonesia dan segala infrastruktur penunjang sepeda motor listrik. Saat ini penggunaan sepeda motor listrik masih meliputi beberapa BUMN yang bekerjasama, seperti WIKA, PLN, Pertamina. Hal ini juga bertujuan agar masyarakat dapat menyesuaikan dengan kondisi sepeda motor listrik yang mana tidak mengeluarkan bunyi dan penggunaanya sedikit berbeda dengan sepeda motor konvensional.

\section{Implikasi Manajerial}

Konsumen melakukan pembelian sepeda motor listrik mempertimbangan atribut yang sesuai dengan kebutuhan atau keinginan konsumen. Perusahaan perlu memasarkan produk yang berfokus pada tingkat kepentingan atribut sepeda motor listrik sehingga konsumen memiliki preferensi kepada merekmerek sepeda motor listrik yang disediakan. Berdasarkan analisis multriatribut Fishbein, keamanan produk adalah atribut yang penting untuk dimiliki oleh sepeda motor listrik. Bagi konsumen, keamanan sepeda motor listrik dapat berbagai hal mulai dari keamanan dalam meminimalkan resiko dalam berkendara serta keamanan dalam komponen-komponen sepeda motor listrik. Hal ini berarti penyedia sepeda motor listrik perlu untuk memberikan informasi terkait keamanan sepeda motor listrik, standar yang digunakan dalam pembuatan dan kompenen-kompenen yang digunakan. Informasi dapat disebarkan melalui website dari perusahaan dan penyebaran brosur pada saat dilakukan pameran. Perusahaan juga dapat melakukan uji coba keamanan produk secara langsung maupun dalam format video pemasaran produk.

Temuan lain dalam analisis multiatribut adalah tentang lama pengisian baterai menjadi atribut yang termasuk sangat penting dalam sepeda motor listrik. Lama pengisian baterai menjadi salah satu pertimbangan masyarakat untuk membeli sepeda motor listrik, dikarenakan waktu yang dibutuhkan lama dibandingkan dengan sepeda motor konvensional. Maka dari itu dalam proses penjualan sepeda motor listrik menggunakan sistem bandling produk. Tujuan dilakukan bandling ini agar konsumen dapat membeli produk dengan harga lebih terjangkau.

\section{SIMPULAN DAN SARAN}

\section{A. Simpulan}

Dari 10 atribut sepeda motor listrik yang digunakan dalam penelitian ini, didapatkan hasil bahwa atribut keamanan dan lama pengisian baterai memiliki tingkat kekuatan kepercayaan sangat penting dan 8 atribut yang lain memiliki kepercayaan
Tabel 4.

Nilai Sikap Responden terhadap Atribut Sepeda Motor Listrik

\begin{tabular}{clcccc}
\hline \hline Kode & \multicolumn{1}{c}{ Atribut } & bi & ei & Ao (bi x ei) & Kategori \\
\hline H7 & Keamanan & 4,37 & 3,69 & 14,96 & Netral \\
H3 & Level Emisi & 4,21 & 3,42 & 14,79 & Netral \\
& Biaya & & & & Netral \\
& Pengisian & & & & \\
H9 & Baterai & 4,14 & 3,33 & 13,56 & Netral \\
H5 & Keandalan & 4,08 & 3,31 & 13,48 & Netral \\
& Lama & & & & \\
& Pengisian & & & & \\
H4 & Baterai & 4,01 & 3,26 & 13,33 & Netral \\
& Agility & & & & \\
& (Kemampuan & & & & \\
& bergerak & & & & \\
H8 & dengan cepat) & 4,00 & 3,25 & 12,93 & Netral \\
H10 & Percepatan & 3,99 & 3,23 & 12,87 & Netral \\
H1 & Harga & 3,96 & 3,19 & 12,58 & Netral \\
H6 & Style (Desain) & 3,79 & 3,17 & 12,08 & \\
H2 & Kecepatan & 3,65 & 3,15 & 12,08 & Netral \\
& & & TOTAL & 132,66 & \\
\hline \hline & & & & &
\end{tabular}

penting. Tingkat evaluasi kepercayaan atribut didapatkan 2 atribut yaitu level emisi dan keamanan memiliki evaluasi yang baik. Maka dari itu didapatkan bahwa dari 10 atribut konsumen merespon netral pada atribut keamanan, lama pengisian baterai, biaya pengisian baterai, keandalan, agility, level emisi, harga, percepatan, kecepatan, dan desain sepeda motor listrik.

\section{B. Saran}

Penelitian ini hanya mengambil atribut yang digunakan dalam mengidentifikasi sikap konsumen diadopsi dari penelitian terdahulu. Atribut tersebut didapatkan dari hasil penelitian di China yang secara infrastruktur dan regulasi berbeda dengan Indonesia. Maka pada penelitian selanjutnya, atribut dapat dilakukan penyesuaian terlebih dahulu dengan kondisi perilaku pembelian konsumen di Indonesia.

\section{DAFTAR PUSTAKA}

[1] Marketeers, "Memahami Pasar Sepeda Motor di Indonesia Terkini," 2015.

[2] ClimateTransparency.org, "Brown To Green: Transisi G20 Menuju Ekonomi Rendah Karbon 2018 Indonesia,” 2018.

[3] L. Bunce, M. Harris, and M. Burgess, "Charge up then charge out? Drivers ' perceptions and experiences of electric vehicles in the UK," Transp. Res. Part A, vol. 59, pp. 278-287, 2014, doi: 10.1016/j.tra.2013.12.001.

[4] Y. M. Pratama, "as R\&D Engineer GESITS,” 2019.

[5] C. Indonesia, "Tren Penjualan Motor Listrik Naik, Warga Papua Ikut Borong," Jakarta, 2019.

[6] D. I. \& M. D. L. Hawkins, Consumer Behavior Building Marketing Strategy, Eleventh E. New York: McGraw-Hill/Irwin, 2010.

[7] M. R. Solomon, Consumer Behavior: Buying, Having, and Being, 12th ed. Essex :Pearson Education, 2017.

[8] D. I. \& M. D. L. Hawkins, Consumer Behavior, 13th ed. New York: McGraw-Hill, 2016.

[9] B. Engel, J.F., Kollat, D.T., Consumer Behavior. New York, 1973.

[10] K. L. Kotle, P. \& Keller, Marketing Management, 15th ed. New Jersey: Pearson Education, Inc, 2016.

[11] S. P. Hoyer, W.D. \& Brown, "Effect of brand awarness on choice for common, repeat-purchase product," J. Consum. Res., p. 17 (2) 141, 1990, doi: $10.1086 / 208544$.

[12] X. He, W. Zhan, and Y. Hu, "Consumer purchase intention of electric vehicles in China: The roles of perception and personality," J. Clean. Prod., vol. 204, pp. 1060-1069, 2018, doi: 10.1016/j.jclepro.2018.08.260.

[13] X. Huang and J. Ge, "Electric vehicle development in Beijing: An analysis 
of consumer purchase intention," J. Clean. Prod., vol. 216, pp. 361-372, 2019, doi: 10.1016/j.jclepro.2019.01.231.

[14] M. Ajzen, I., \& Fishbein, "Attitude behavior relations: A theoritical analysis and review of empirical research.," Psychol. Bull., vol. 84(5), pp. 888-918, 1997, doi: doi.org/10.1037/0033-2909.84.5.888.

[15] M. Oppermann, "Travel life cycle," Ann. Tour. Res., vol. 22(3), pp. 535552, 1995, doi: doi.org/10.1016/0160-7383(95)00004-P.
[16] Y. Han. H., \& Kim, “An Investigation of Green hotel customers' descision formation: Developing an extended model of the theory of planned behavior.," Int. J. Hosp. Manag., vol. 29(4), pp. 659-668, 2010, doi: doi.org/10.1108/02634500610711842.

[17] J. R. Bettman, N. Capon, and R. J. Lutz, "Multiattribute measurement models and multiattribute attitude theory: A test of construct validity," $J$. Consum. Res., vol. 1, no. 4, p. 1, 1975, doi: 10.1086/208602. 